\title{
In Which Type of Healthcare Do Patients Show Greater Loyalty? (Public Sector Management vs. Public- Private Partnership)
}

¿En qué tipo de asistencia el paciente manifiesta una mayor lealtad? (Gestión pública vs. colaboración público-privada)

\author{
A que tipo de assistência o paciente \\ manifesta uma maior lealdade? \\ (Gestão pública vs. colaboração \\ público-privada) \\ Remedios Calero, PhD ${ }^{1 *}$; \\ Martina G. Gallarza, PhD²
}

Received: March 9th, 2017 / Accepted: May 21st, 2018

Dor: http://dx.doi.org/10.12804/revistas.urosario.edu.co/revsalud/a.7259

To cite this article: Calero R, Gallarza M. In Which Type of Healthcare Do Patients Show Greater Loyalty? (Public Sector Management vs. Public-Private Partnership). Rev Cienc Salud. 2018;16(3):492-509. DoI: http://dx.doi.org/10.12804/revistas.urosario.edu.co/revsalud/a.7259

\section{Abstract}

Introduction: The present study analyses the patients behavior in a setting with different management types: public sector management and public-private partnership. More specifically, the objective is to establish in which healthcare type (hospitalization, ambulatory surgery, emergencies, outpatients consultation) do the patients show a stronger loyal behavior when they are in different management scenarios. Material and methods: A descriptive analysis based on secondary data collected from an internal database of the Conselleria de Sanidad of the Valencian Community in Spain, a scenario with two different healthcare management types (public sector management and public-private partnership) was conducted. Results: Higher patient flows in two healthcare types (emergency and outpatient consultation); disparate growth of the patients' net basis; partnership favors maintaining the relationship with the patient thus preventing dropout; specialization of the public-private partnership in an assistance type: ambulatory

1 Hellín Hospital, Hellín, Spain.

Corresponding author: remedios.calero@mail.ucv.es

2 'Universidad de Valencia, Valencia, Spain. 
surgery. Conclusion: The obtained results identify the healthcare types with higher patients' loyalty, as well as the extent to which the management type affects this loyalty behaviour.

Keywords: Patients' loyalty behaviour, healthcare services management, healthcare services marketing, consumer behavior.

\title{
Resumen
}

Introducción: el presente trabajo analiza el comportamiento del paciente en un entorno con diferentes tipos de gestión: pública y colaboración público-privada. Más concretamente, el objetivo es conocer en qué tipo de asistencia (hospitalización, cirugía sin ingreso, urgencias, consultas externas) el paciente muestra un comportamiento de lealtad cuando se encuentra ante diferentes escenarios de gestión. Materiales y métodos: análisis descriptivo a partir de datos secundarios obtenidos de una base de datos interna de la Conselleria de Sanidad en la Comunidad Valenciana (España), un escenario con dos modelos de gestión sanitaria (pública y colaboración público-privada). Resultados: mayores flujos de pacientes en dos tipos de asistencia (urgencias y consultas externas), crecimiento dispar de la base neta de pacientes, el partenariado favorece el mantenimiento de la relación con el paciente, evitando su deserción, especialización de la colaboración público-privada en un tipo de asistencia: cirugía sin ingreso. Conclusión: los resultados obtenidos identifican los tipos de asistencia con mayor lealtad del paciente, así como en qué medida el tipo de gestión afecta a esta lealtad.

Palabras clave: administración hospitalaria, administración de los servicios de salud, comercialización de los servicios de salud, comportamiento del consumidor.

\section{Resumo}

Introdução: o presente trabalho analisa o comportamento do paciente em um ambiente com diferentes tipos de gerenciamento: pública e colaboração público-privada. Mais especificamente, o objetivo é saber em que tipo de assistência (hospitalização, cirurgia sem admissão, emergências, consultas externas) o paciente mostra comportamento de lealdade quando há diferentes cenários de gerenciamento. Materiais e métodos: análise descritiva a partir de dados secundários obtidos a partir de uma base de dados interna do Conselho Valenciano de Saúde (Espanha), um cenário com dois modelos de gestão da saúde (pública e colaboração público-privada). Resultados: maiores fluxos de pacientes em dois tipos de assistência (emergências e consultas ambulatoriais); crescimento desigual da base líquida de pacientes; a parceria favorece o mantimento do relacionamento com o paciente, evitando sua deserção; especialização da colaboração público-privada em um tipo de assistência: cirurgia sem admissão Conclusões: os resultados identificam os tipos de assistência a lealdade mais paciente e em que medida tipo de gestão afeta essa lealdade.

Palavras-chave: administração hospitalar, administração de serviços de saúde, marketing de serviços de saúde, comportamento do consumidor.

\section{Introduction}

\author{
This work, based on a study on the patients' loyalty behavior, pursues a double objective; \\ 1 firstly, to explore in which healthcare assistance type (hospitalization, ambulatory \\ surgery, emergencies, outpatients consultations) the patient presents a higher or lower \\ loyalty behavior. Secondly, it aims at establishing if this behavior is different depending
}


on the healthcare management model (public sector management or public-private partnership - Alzira Model, as it is called in this Spanish region ${ }^{3}$ ).

To this end, the chosen setting is the Region of Valencia where, based on the information of an internal database from the Regional Health Department, the patients' recruitment, retaining and dropout data, as well as the net growth of the patient base, the natural growth rate and the market share were studied as strategic variables of loyalty.

The obtained results are intended to be used in future as a guide for operators and researchers of healthcare services when it comes to predict the patients' behavior and to define the service portfolio, particularly in competitive environments, with capitation financing and patient's free choice of doctor (1).

In consumer behavior research, the first loyalty definitions are based on behavioural outcomes, considering only the consumer's buyback behavior (2-6). Against the background of this initial reality, a critical stream was stablished in the literature towards assimilating loyalty to repeated purchasing patterns, focusing on its attitudinal and emotional component, thus categorizing the loyalty components, from an always multidimensional approach, into cognitive, affective and conative (7-15). Loyalty is so defined from a predisposition-based standpoint (attitudinal) that is combined with the repeated purchasing (behavioral) of a specific service.

In order to describe the particularity of the behavior of the patient acting as a healthcare service user, in the following we will detail how the literature on healthcare marketing places special emphasis on the particular idiosyncrasy of this service: the high degree of participation of the patient and the understanding of loyalty behaviour as the continuity of care.

As a first special feature, the literature suggests that the idiosyncrasy characteristic of the healthcare service is a fundamental aspect for understanding loyalty within the framework of this service. On a general basis, its intangible and perishable nature generate a higher difficulty to achieve loyalty at the service level rather than at the product' level (16). Likewise, the critical nature of the healthcare assistance should be noted. By way of example, authors like Jacoby and Kyner, when defining loyalty, argue that the client chooses among $\mathrm{N}+1$ alternatives, where $\mathrm{N}$ represents the different providers and 1 the possibility of not taking any service (17). However, this criticality of the healthcare service is what makes it a necessary service, thus eliminating for the patient this last possibility of not taking the service. In this way, we can see how the healthcare services idiosyncrasy affects the nature of loyalty, thus promoting the appearance of a specific literature on loyalty behaviour focused on the healthcare service.

It is known as the Alzira Model because Alzira was the first town operating under this type of partnership: public ownership, private management. 
A second characteristic feature of this service, that has an impact on the achieved loyalty level, is the high consumer participation degree. Its increased participation degree in the co-creation of the healthcare service produces a situation in which the positive emotions become critical in the consumer choices and, therefore, in their loyalty $(15,18$, 19). In other words, in services loaded with a special criticality as the healthcare services do, the affective aspects experienced by the consumers in the time they are provided and co-created determine their future behavior $(20,21)$. Then, because of these interactions and the affectivity experienced by the patient, we could establish how their "intention to keep with a specific doctor is a valuable measure to predict future behavior" (22).

However, in view of the particularities of the value co-creation associated with the healthcare services, in the doctor-patient relationship the qualities of both the service provider (supply) and the patient (demand) should be considered. Under this double vision, Rundle-Thiele and Russell-Bennet refer to the patient's particular characteristics (age, gender, habitat, state of health, etc.), as well as to the conceptual characteristics (frequency of medical visits, contact regularity, etc.) as factors that have an impact on the loyalty expressed by the patient (20). Regarding the service provider, Torres and colleagues consider the reputation of the physician to be the best loyalty antecedent since it has an influence on the patient's confidence and the satisfaction he/she has with the provided service, affecting therefore his/her loyalty (23).

A third characteristic covered by the healthcare marketing literature is that loyalty is understood as continuity in attendance. In the healthcare realm, loyalty is considered non-exclusive, where exclusivity is understood rather as a priority. In other words, with a certain normality it is accepted that patients occasionally turn to other provider looking for a second opinion or in case of an emergency, if they give priority to their regular doctor (24). Under this vision, Roberge et al difference between generally loyal and generally disloyal patients. The former ones are those who consult their physician most of their health needs, while the generally disloyal patients do not maintain a stable relation with their physicians, indiscriminately consulting different staff. Going a step further, these authors even talk about "dependent patients who require approval from their doctor of reference in case of any health problem" (24). This idea is treated in the literature by other authors such as Freeman and Hjordahl who point out, additionally, how the patient can show his/her loyalty despite not having received the service for a while because there was no need to. Nevertheless, whenever the patient needs medical attention, he/she will come to the health center and seek the physician he/she trusts (25).

As a result of the above, loyalty, seen from the perspective of the healthcare service, can be understood as the continuity of healthcare (25). To put it another way, loyalty is constituted as the provision of healthcare assistance by a professional, a healthcare team or a medical institute to a patient over time; it is particularly relevant in the case of chronic patients or 
with serious illnesses. From the perspective of the assistance continuity, the physician-patient relationship plays an essential role for maintaining the patient's loyalty $(25,26)$.

As a consequence of the existence of these characteristics, the usefulness of loyalty as a management instrument is recognized by multiple authors $(15,17,20-23,26-32)$. In this light, the healthcare marketing literature shows how the "concept of loyalty in the healthcare realm has developed from beingn considered just an important value to be the main success and survival determinant of the healthcare organizations” (33). It allows attracting and maintaining its benefits by means of financing systems such as capitation or act payment, it furthermore betters the results for the patient achieving his/her confidence. Likewise, the evolution of the healthcare sector itself, in which the traditional monopolies are affected by the deregulation and the introduction of the free competition, leads to consider that the patients' loyalty is a necessary condition for not being left behind by their competitors (34). In this context, "the healthcare providers have much to gain if they analyze the patients' loyalty" (22).

With this background as a description of the patient's loyalty behavior, we propose below an empirical study with a view to measure variations in this behavior in accordance with the types of assistance and the healthcare management model (public sector management or public-private partnership).

\section{Materials and methods}

W

ith the aim of analyzing the patient's loyalty behavior, the chosen setting for this study was the Valencian Community, a Spanish region where patient's freedom to choose physician and healthcare center exist, being suitable for a study like the one proposed here. This region structures its healthcare system according to the geography into 24 health departments, where the patients are initially assigned to a specific department but with the possibility for the patients to go to another one searching for healthcare assistance (35). In this way, since the patients' preferences are reflected in their healthcare center choice, their loyalty behavior towards the center initially assigned can be observed. To analyze this behavior, strategic loyalty variables adjusted to the setting of the Region of Valencia were used, as it is shown in figure 1.

These parameters, indicating in parenthesis the calculation formula based on the nomenclature used in figure 1, allow measuring the acquisition (C/A), dropout (D/A) and retention (E/A) rates, as well as the net growth of the patients' base (B/E) and the Natural Growth Rate index $\left([\mathrm{A}+\mathrm{B}-\mathrm{E}]_{\mathrm{n}} / \text { [A } \mathrm{B}-\mathrm{E}\right]_{\mathrm{n}-1}$ ) as expression of their loyalty behavior in the light of demand, where it should also be analyzed together in connection with supply by the market share $\left([\mathrm{A}+\mathrm{B}-\mathrm{E}]_{\mathrm{Dpt.x}} /[\mathrm{A}]_{\text {C.V. })}\right.$ ), aiming at providing a better understanding of 
its relation with the organization's profitability (36). The market share is a parameter that aims at explaining the purchases of an organization in relation to its competitors $(37,38)$. It shows, in this way, the market percentage or segment in which the company moves (39). It is, therefore, a competition measurement that aims at assessing the relative loyalty from both approaches: demand and supply.

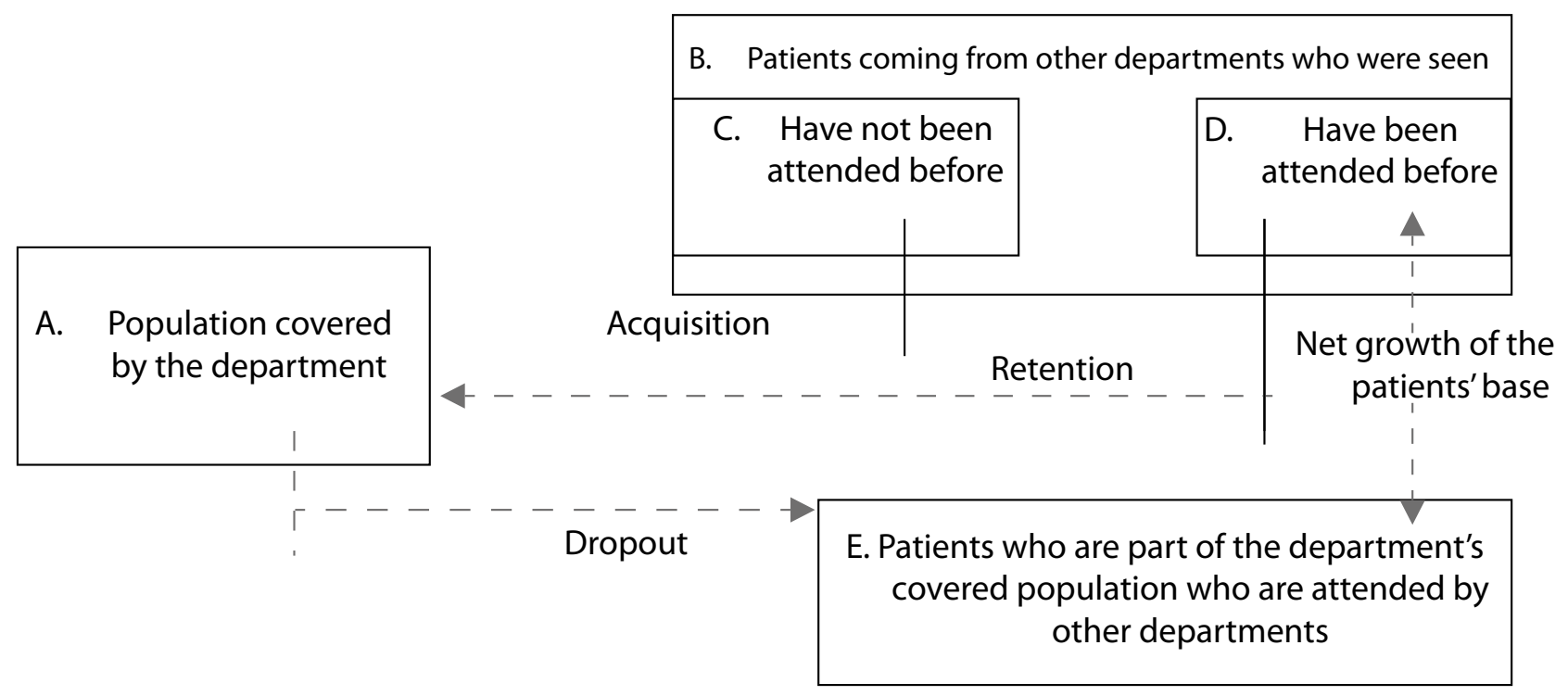

Figure 1. Loyalty measures and parameters adjusted to the healthcare ambit of the Valencian Community

Source: Calero and Gallarza (40)

Likewise, figure 1 explains the parameters that we will analyze from a descriptive approach, providing its formula, according to the nomenclature established in figure 1 (40). Once they have been defined, we seek to offer these measurements from a comparative perspective per assistance type (hospitalization, ambulatory surgery, emergencies and outpatients consulting). In a descriptive and synchronic mode, based on secondary internal data of the Healthcare Counseling, calculations for all healthcare departments of the Region of Valencia for the year 2012 have been made. In the same way, from a comparative perspective, and considering that five of the 24 Healthcare Departments of this Region operate on a private basis (the so called Alzira Model-public hospitals with a private management), we aim to compare the results between the publicly managed departments and those managed by public-private partnership (the latter are La Ribera, Torrevieja, Denia, Manises and Elx-Crevillent). Going a step further, we will even try to establish if there is a single loyalty pattern in all departments managed according to the same formula. 
For all the conducted analyses, secondary data obtained from an internal database of the Healthcare Counseling of the Region of Valencia, called compas were considered (41). compas gathers the attendance flows among the Healthcare Departments. The figures under study correspond to over a million registrations to be analyzed and following conceptual and methodological guidelines:

a. Every parameter is calculated as a proportion of the assigned population. By this we try to eliminate the bias derived by the size of the hospital, since endowment and infrastructure usually conform with the covered population of each department.

b. While acquisition and retention are applied to the number of patients of other departments who are attended, dropout refers to the loyalty behavior of the patients initially assigned to a specific department.

c. Considering the incidence of acquisition, retention and dropout, we will analyze the net growth of the patients' base, the natural growth rate and the market share.

- The net growth represents the balance between attended patients of other departments (both acquired and retained) and those patients assigned to the department who have defected.

- The natural growth rate shows the annual increase of the department's population, including both the initially assigned population and the variations due to the patients' behavior; for this reason, in our objective of describing the patients' loyalty behavior we did not include those components corresponding to the variations related to the initially assigned population.

- The market share is a competitive measurement that allows us to determine the achieved relative loyalty level. From this perspective, we observe how this share varies because of the different population flows. For this purpose, we considered only the balance between the attended patients that do not belong to the department and the patients of the department attended in another one, divided by the total population, eliminating the effect of the assigned population.

$d$. The attendances in which the patient necessarily must go to another department for medical assistance because the needed service is not available in his/her department of origin were not included. In such cases, the patient's behavior does not imply an expression of his/her preferences.

e. The figures related to the Healthcare Department Valencia-La Fe, that, due to their volume, cannot be compared in the same graphic, appear in the upper right side with a higher scale. 


\section{Results}

From a descriptive perspective, after having analyzed the different parameters in accordance with the healthcare type (hospitalization, ambulatory surgery, emergencies and outpatients consulting) and the healthcare department, we present the obtained results in form of figures and graphs organized in a decreasingly, thus allowing, in turn, the visualization of the relative position of each Department.

\section{Descriptive Analysis of the Patient Acquisition}

First, the reading of the ranking (table 1) by healthcare type (columns) determines that the highest patient acquisition takes place in medical emergency and outpatient consultancy, and in a lower degree in hospitalization and ambulatory surgery. This is due basically to the particularity of these healthcare types, so that most typically the patient comes to emergency or outpatient consultancy a higher number of times than the times he/she is hospitalized or undergoes ambulatory surgery.

Secondly, the reading by healthcare department (rows) shows big differences in the acquisition rates of the departments with an Alzira Model management in relation to the healthcare type. The acquisition figures of the Department of Manises stand out, it is the concession with the highest values in all healthcare types except for emergency $(0.93 \%$ in hospitalization; $0.80 \%$ in ambulatory surgery; and $3.01 \%$ in outpatient consultation), thus placing this one among the three departments with the highest acquisition rates in the four healthcare types. Subsequently, La Ribera achieves a considerable acquisition of $2.54 \%$ in emergencies, of $1.57 \%$ in outpatient consultation, of $0.31 \%$ in ambulatory surgery, and of $0.56 \%$ in hospitalization, thus belonging to the departments with a higher patient acquisition in the four healthcare types. Likewise, Elx-Crevillent presents a relatively outstanding position in some assistance types such as hospitalization and ambulatory surgery. Torrevieja and Denia, by contrast, show substantially low acquisition rates. Furthermore, the patient acquisition level shown by the concessions in ambulatory surgery attracted our attention, since four out of the seven departments with the highest patient acquisition have an Alzira Model management. 
Table 1. Acquiring and retention rates by healthcare assistance type

Acquisition Rates

\begin{tabular}{|c|c|c|c|c|c|c|c|c|}
\hline & Hospitalization & $\%$ & Ambul. Surgery & $\%$ & Emergencies & $\%$ & Outp. Consultation & $\%$ \\
\hline 1 & La Fe & 7.08 & La Fe & 1.22 & La Fe & 20.71 & La Fe & 18.06 \\
\hline 2 & Alicante & 1.22 & Manises & 0.80 & Requena & 4.29 & General Valencia & 3.32 \\
\hline 3 & Manises & 0.93 & General Valencia & 0.48 & Alicante & 3.94 & Manises & 3.01 \\
\hline 4 & Clínico & 0.80 & Castellón & 0.33 & Clínico & 3.53 & Alicante & 2.70 \\
\hline 5 & General Valencia & 0.65 & La Ribera & 0.31 & La Ribera & 2.54 & Clínico & 2.29 \\
\hline 6 & Elx-Crev. & 0.63 & Elx-Crev. & 0.20 & General Valencia & 2.34 & Elche & 1.71 \\
\hline 7 & San Juan & 0.59 & Torrevieja & 0.16 & Sa gunto & 2.31 & La Ribera & 1.57 \\
\hline 8 & La Ribera & 0.56 & Alicante & 0.16 & Manises & 2.09 & Dr. Peset & 1.32 \\
\hline 9 & Elche & 0.49 & Dr. Peset & 0.12 & San Juan & 2.08 & Castellón & 1.27 \\
\hline 10 & Castellón & 0.48 & Requena & 0.09 & Elche & 1.89 & Requena & 1.20 \\
\hline 11 & Dr. Peset & 0.42 & Elche & 0.08 & Elx-Crev. & 1.87 & San Juan & 1.14 \\
\hline 12 & La Plana & 0.32 & La Plana & 0.05 & Dr. Peset & 1.55 & Elx-Crev. & 0.79 \\
\hline 13 & Torrevieja & 0.27 & Arnau & 0.05 & Denia & 1.41 & Arna u & 0.70 \\
\hline 14 & Requena & 0.26 & Castellón & 0.05 & Castellón & 1.14 & La PIana & 0.65 \\
\hline 15 & Denia & 0.25 & San Juan & 0.04 & Torrevieja & 1.07 & Sagunto & 0.65 \\
\hline 16 & Sagunto & 0.20 & Sagunto & 0.04 & Arnau & 1.05 & Orihuela & 0.47 \\
\hline 17 & Arnau & 0.16 & Xàtiva-Ont. & 0.03 & Gandia & 1.04 & Xàtiva-Ont. & 0.45 \\
\hline 18 & Xà ti va-Ont. & 0.14 & Gandia & 0.03 & Villajoyosa & 0.98 & Gandia & 0.43 \\
\hline 19 & Orihuela & 0.12 & Orihuela & 0.02 & La Plana & 0.95 & Torrevieja & 0.40 \\
\hline 20 & Gandia & 0.12 & Denia & 0.02 & Xà tiva-Ont. & 0.09 & Elda & 0.36 \\
\hline 21 & Alcoy & 0.11 & Elda & 0.02 & Elda & 0.68 & Villa joyosa & 0.33 \\
\hline 22 & Villajoyosa & 0.11 & Vinaroz & 0.01 & Vinaroz & 0.66 & Vina roz & 0.24 \\
\hline 23 & Elda & 0.10 & Villajoyosa & 0.01 & Orihuela & 0.63 & Alcoy & 0.23 \\
\hline 24 & Vinaroz & 0.08 & Alcoy & 0.01 & Alcoy & 0.53 & Denia & 0.18 \\
\hline
\end{tabular}

\section{Retention Rates}

\begin{tabular}{|c|c|c|c|c|c|c|c|c|}
\hline & Hospitalization & $\%$ & Ambul. Surgery & $\%$ & Emergencies & $\%$ & Outp. Consultation & $\%$ \\
\hline 1 & La Fe & 1.77 & La Fe & 0.304 & La Fe & 10.17 & La Fe & 42.45 \\
\hline 2 & Alicante & 0.29 & General Valencia & 0.083 & Alicante & 1.82 & General Valencia & 8.06 \\
\hline 3 & Clínico & 0.17 & Clínico & 0.081 & Clínico & 1.08 & Alicante & 5.95 \\
\hline 4 & La Ribera & 0.13 & Alicante & 0.036 & Requena & 0.88 & Clínico & 5.77 \\
\hline 5 & General Valencia & 0.13 & Dr. Peset & 0.035 & General Valencia & 0.85 & Dr. Peset & 3.01 \\
\hline 6 & San Juan & 0.11 & La Ribera & 0.033 & La Ribera & 0.67 & Castellón & 2.29 \\
\hline 7 & Dr. Peset & 0.11 & Requena & 0.027 & Elx-Crev. & 0.62 & Elche & 2.24 \\
\hline 8 & Manises & 0.09 & Manises & 0.021 & Dr. Peset & 0.61 & La Ribera & 2.18 \\
\hline 9 & Elche & 0.09 & Arnau & 0.011 & Manises & 0.60 & Manises & 1.85 \\
\hline 10 & Castellón & 0.07 & Elche & 0.009 & San Juan & 0.48 & San Juan & 1.59 \\
\hline 11 & La Plana & 0.04 & Elx-Crev. & 0.008 & Elche & 0.48 & Arnau & 1.38 \\
\hline 12 & Elx-Crev. & 0.03 & Torrevieja & 0.008 & Sagunto & 0.43 & Requena & 1.11 \\
\hline 13 & Arnau & 0.03 & San Juan & 0.007 & Arnau & 0.28 & La Plana & 0.98 \\
\hline 14 & Requena & 0.02 & Castellón & 0.006 & La Plana & 0.26 & Sagunto & 0.74 \\
\hline 15 & Sagunto & 0.02 & Sagunto & 0.005 & Xà tiva-Ont. & 0.21 & Xà tiva-Ont. & 0.52 \\
\hline 16 & Torrevieja & 0.02 & La Plana & 0.003 & Torrevieja & 0.20 & Elda & 0.45 \\
\hline 17 & Elda & 0.02 & Xà tiva-Ont. & 0.003 & Castellón & 0.20 & Orihuela & 0.37 \\
\hline 18 & Orihuela & 0.02 & Denia & 0.003 & Denia & 0.19 & Gandia & 0.36 \\
\hline 19 & Gandia & 0.02 & Orihuela & 0.003 & Elda & 0.17 & Villajoyosa & 0.32 \\
\hline 20 & Xà tiva-Ont. & 0.01 & Villajoyosa & 0.002 & Gandia & 0.15 & Elx-Crev. & 0.29 \\
\hline 21 & Alcoy & 0.01 & Elda & 0.001 & Villajoyosa & 0.13 & Alcoy & 0.23 \\
\hline 22 & Villajoyosa & 0.01 & Gandia & 0.001 & Orihuela & 0.11 & Torrevieja & 0.22 \\
\hline 23 & Denia & 0.01 & Vinaroz & 0.000 & Vinaroz & 0.11 & Vinaroz & 0.21 \\
\hline 24 & Vinaroz & 0.01 & Alcoy & 0.000 & Alcoy & 0.07 & Denia & 0.10 \\
\hline
\end{tabular}




\section{Descriptive Analysis of the Patient Retention}

As shown in table 1, the higher patient retention values are registered in outpatient consultation and medical emergency (columns). However, in hospitalization and ambulatory surgery, patient retention is hardly seen. Again, this fact may be caused by the particularity of the healthcare assistance type, since the number of outpatient consultancies and medical emergencies where a patient goes for assistance is higher than the number of hospitalizations or surgeries with no admission he/she undergoes. Considering private-public partnership (bold written), the highest values correspond to La Ribera and Manises, but the values of Elx-Crevillent under medical emergencies are also outstanding (rows). Torrevieja and Elx-Crevillent have average positions, while Denia is the department with the lowest patient retention. It must be pointed out that the best positions of the concessions are found in the ambulatory surgery, and that the outpatients consultations occupy the lowest positions.

\section{Descriptive Analysis of the Patient Dropout}

According to table 2, the highest dropout rates are registered by the outpatients consultation, followed by emergencies (columns). Regarding the healthcare management model (rows) we established that the departments with partnership management have relatively low positions, especially by hospitalization and ambulatory surgery. However, we found big differences in the behavior of this rate among the public-private concessions. Manises shows a high patient dropout rate, while Denia and Torrevieja present very low dropout rates, whereby the latter concession is the Healthcare Department with the lowest dropout in ambulatory surgery, emergencies and outpatient consultations.

Table 2. Dropout rate by healthcare type

\begin{tabular}{|l|l|l|}
\hline Hospitalization & $\%$ & Ambul. Surgery \\
\hline Arnau & 2.28 & Requena \\
\hline Requena & 1.29 & Arnau \\
\hline Dr. Peset & 1.16 & Xàtiva-Ont. \\
\hline Manises & 1.16 & Gandia \\
\hline General Valencia & 1.10 & Dr. Peset \\
\hline Gandia & 0.94 & Alcoy \\
\hline Xàtiva-Ont. & 0.94 & La Fe \\
\hline San Juan & 0.89 & Manises \\
\hline Sagunto & 0.86 & General Valencia \\
\hline Vinaroz & 0.82 & Clínico \\
\hline Alcoy & 0.78 & Orihuela \\
\hline Clínico & 0.77 & Sagunto \\
\hline Orihuela & 0.77 & San Juan \\
\hline Elche & 0.72 & La Ribera \\
\hline La Plana & 0.69 & Alicante \\
\hline Elx-Crev. & 0.63 & La Plana \\
\hline La Fe & 0.58 & Elche \\
\hline La Ribera & 0.58 & Castellón \\
\hline Villajoyosa & 0.54 & Elda \\
\hline Elda & 0.51 & Elx-Crev. \\
\hline Denia & 0.46 & Denia \\
\hline Torrevieja & 0.40 & Vinaroz \\
\hline Castellón & 0.36 & Villajoyosa \\
\hline Alicante & 0.36 & Torrevieja \\
\hline
\end{tabular}

\begin{tabular}{cl} 
\% & Emergencies \\
\hline 0.68 & Arnau \\
0.56 & Dr. Peset \\
0.54 & General Valencia \\
0.44 & San Juan \\
0.39 & La Fe \\
0.30 & Manises \\
0.28 & Clínico \\
0.27 & Elche \\
0.26 & Sagunto \\
0.24 & Requena \\
0.22 & Elx-Crev. \\
0.22 & La Ribera \\
0.15 & Alicante \\
0.14 & Gandia \\
0.13 & Xàtiva-Ont. \\
0.13 & Orihuela \\
0.10 & Alcoy \\
0.09 & La Plana \\
0.09 & Elda \\
0.09 & Villajoyosa \\
0.09 & Castellón \\
0.07 & Vinaroz \\
0.06 & Denia \\
0.05 & Torrevieja \\
\hline
\end{tabular}

\begin{tabular}{clc}
$\%$ & Outp. Consultation & $\%$ \\
\hline 9.25 & Clínico & 12.42 \\
6.62 & Dr. Peset & 12.19 \\
6.00 & Arnau & 11.54 \\
5.40 & Manises & 9.28 \\
4.97 & General Valencia & 6.90 \\
4.89 & Requena & 6.34 \\
3.83 & San Juan & 5.86 \\
2.86 & Sagunto & 5.69 \\
2.83 & La Plana & 5.59 \\
2.59 & Gandia & 5.14 \\
2.13 & La Fe & 5.03 \\
2.02 & Xàtiva-Ont. & 4.63 \\
2.01 & Elx-Crev. & 4.13 \\
1.99 & La Ribera & 3.63 \\
1.91 & Alcoy & 3.27 \\
1.89 & Vinaroz & 3.12 \\
1.70 & Orihuela & 3.02 \\
1.69 & Elche & 3.00 \\
1.47 & Denia & 2.67 \\
0.98 & Elda & 2.60 \\
0.96 & Castellón & 2.17 \\
0.94 & Alicante & 2.13 \\
0.88 & Villajoyosa & 2.12 \\
0.85 & Torrevieja & 1.83
\end{tabular}


Consequently, from the conducted analysis it can be inferred that the departments managed according to the Alzira Model present a particularly low patient dropout. In other words, it seems that this healthcare management model favors the maintenance of relations with the patient. However, it most be noted that we found an exception to this pattern in the Department of Manises whose dropout rates reach one of the highest levels, in the year-on-year and in the healthcare type figures, although in recent years these are decreasing.

\section{Patients' Base Net Growth Analysis}

As it is shown in figure 2, only the Departments of La Fe, Alicante and La Ribera reach a net growth of their patients' base in the four analyzed healthcare types. Other departments, like Castellon, Clinico and Elx-Crevillent register an increase of their patients' base in three of the four assistance types. In this way, the concession of Elx-Crevillent shows values higher than 1 in hospitalization, ambulatory surgery and emergencies. Manises achieves only an increase of its patients' net base in ambulatory surgery, while this base decreases in the other three healthcare types. Torrevieja produces values higher than 1 in ambulatory surgery as well as in emergencies, showing a relevant decrease in outpatient consultation. Denia enhances its patients' base only in emergencies, with a relevant decrease in outpatient consultations. In healthcare type, the figures presented by the public-private concessions in ambulatory surgery stand out, thus confirming a specialization of these departments in this surgery type and resulting in a higher volume of acquired and retained patients than of defected patients. Moreover, at a more global level, it most be noted that 11 departments show a reduction of their patient's net base in all the studied healthcare types, a fact that should be analyzed from a management approach.

\section{Analysis of the natural growth rate}

We looked for differences in the patients' behavior in relation to the healthcare type (figure 2). In this way, we find the highest variation in outpatient consultations and emergencies. Differentiating by healthcare department, after La Fe, the departments of Elx-Crevillent, Denia and Manises present the best results with positive values in all healthcare types. The year-on-year increase by outpatient consultation and hospitalization in Elx-Crevillent is particularly striking, as it does by outpatient consultation and emergencies in Manises, this most of all because of the augmented patient acquisition registered by the latter. Torrevieja, for its part, shows a positive natural growth rate by all healthcare types, except for hospitalization and outpatient consultation; while La Ribera presents only two positive values in emergencies. Ultimately, the observation and analysis of this index reflect the fast and good evolution of the private-public concessions which improve their population figures year on year thanks to the behavior shown by the patients. 


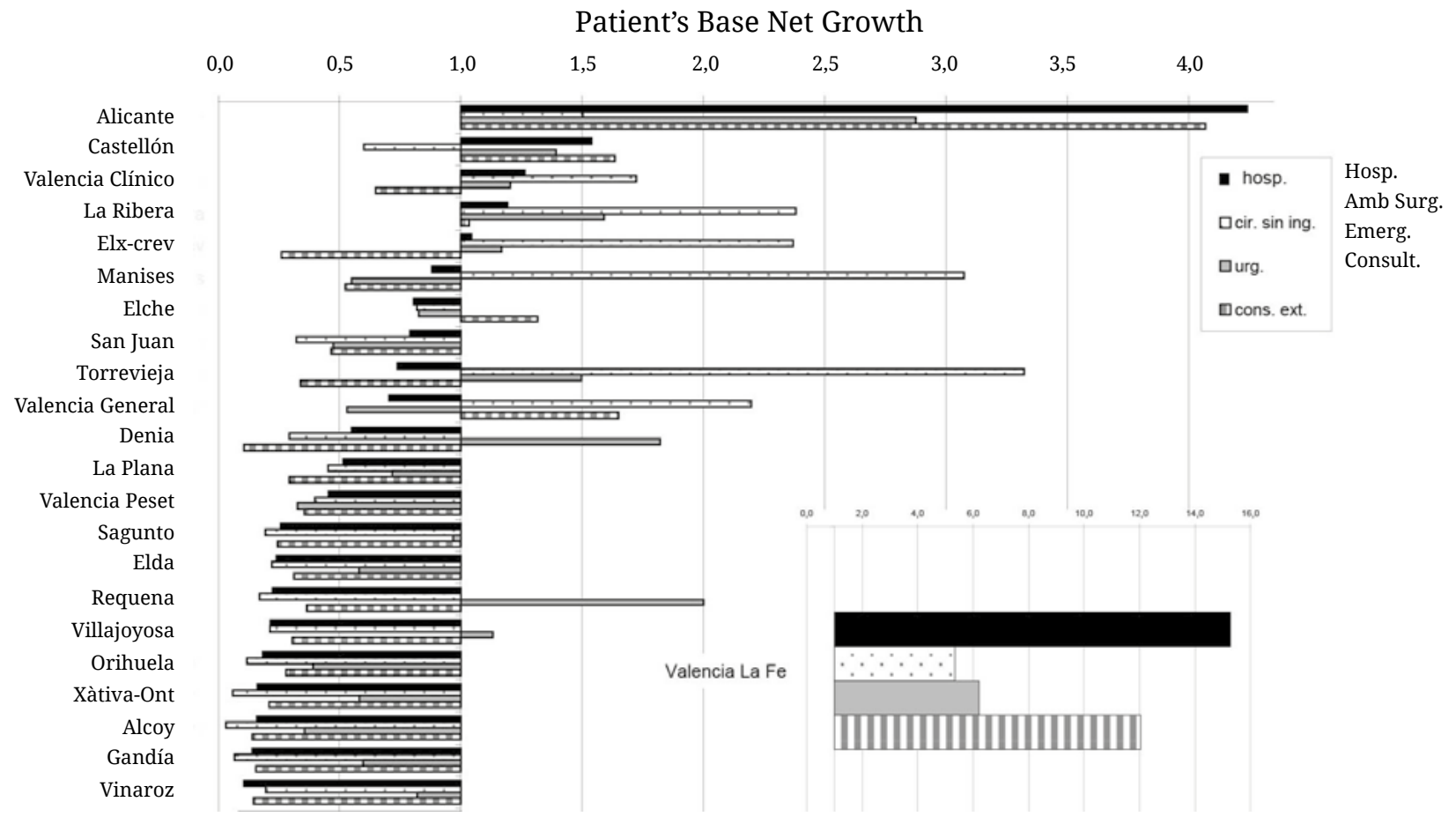

\section{Natural Growth Rate Index}

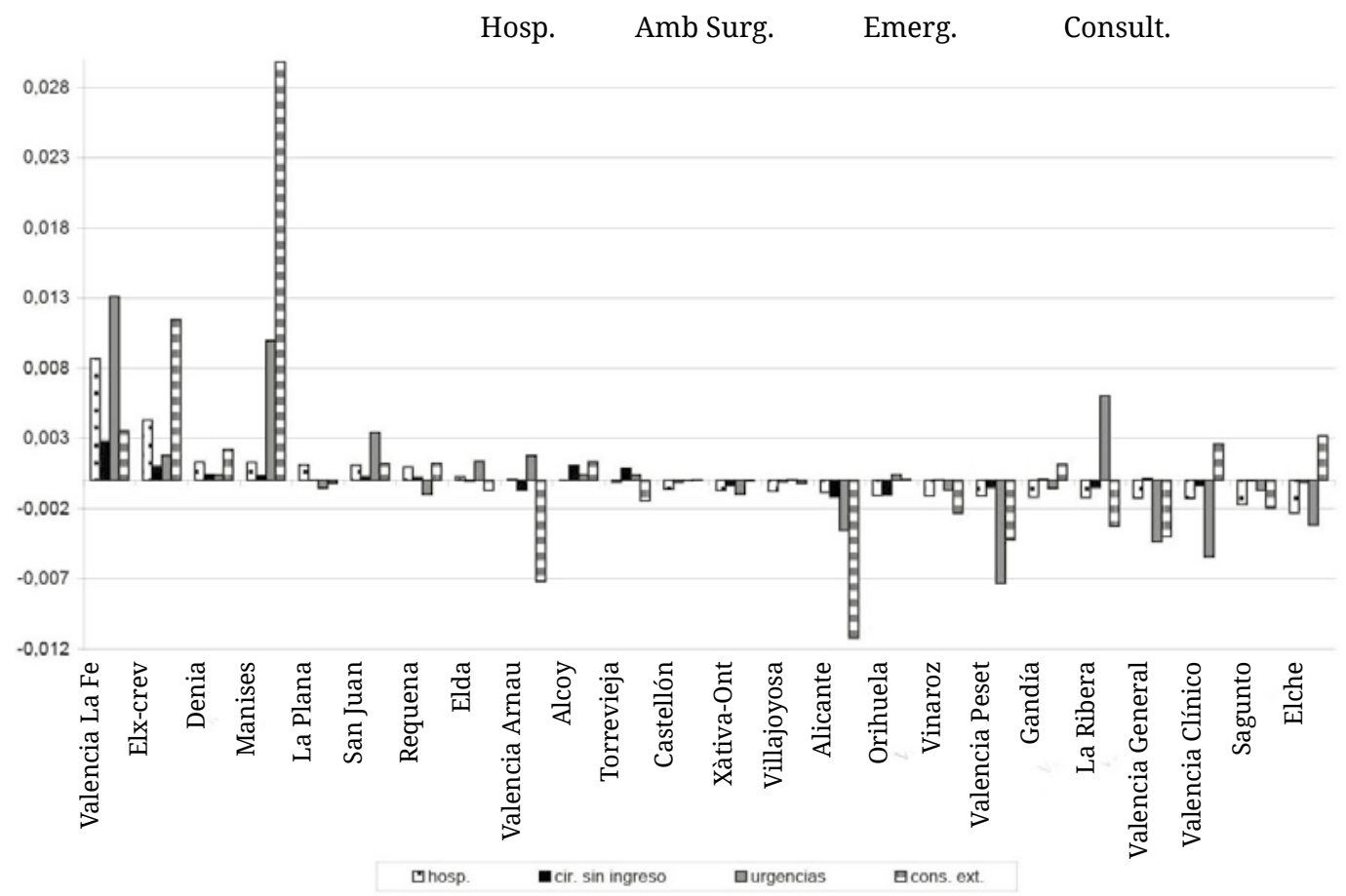

Figure 2. Patients' base net growth and Natural Growth Rate index by healthcare 


\section{Analysis of the Market Share}

Figure 3 shows how the highest inter-department patients' flow is found in outpatient consultation and in medical emergencies. When differentiating by healthcare department, we establish that the only concession that can increase its market share in all the analyzed healthcare types is La Ribera. Torrevieja achieves positive values in ambulatory surgery and emergencies, with a slight fall in hospitalization and a more notable decline in outpatient consultations. The same pattern is observed in the concessions of Elx-Crevillent and Denia, and in the latter is a slight decrease of the market share in relation to the ambulatory surgery. In this way, we can establish how the different departments show the same population market share for all healthcare types. Ultimately, Manises has a reduced market share in all healthcare types except for ambulatory surgery.

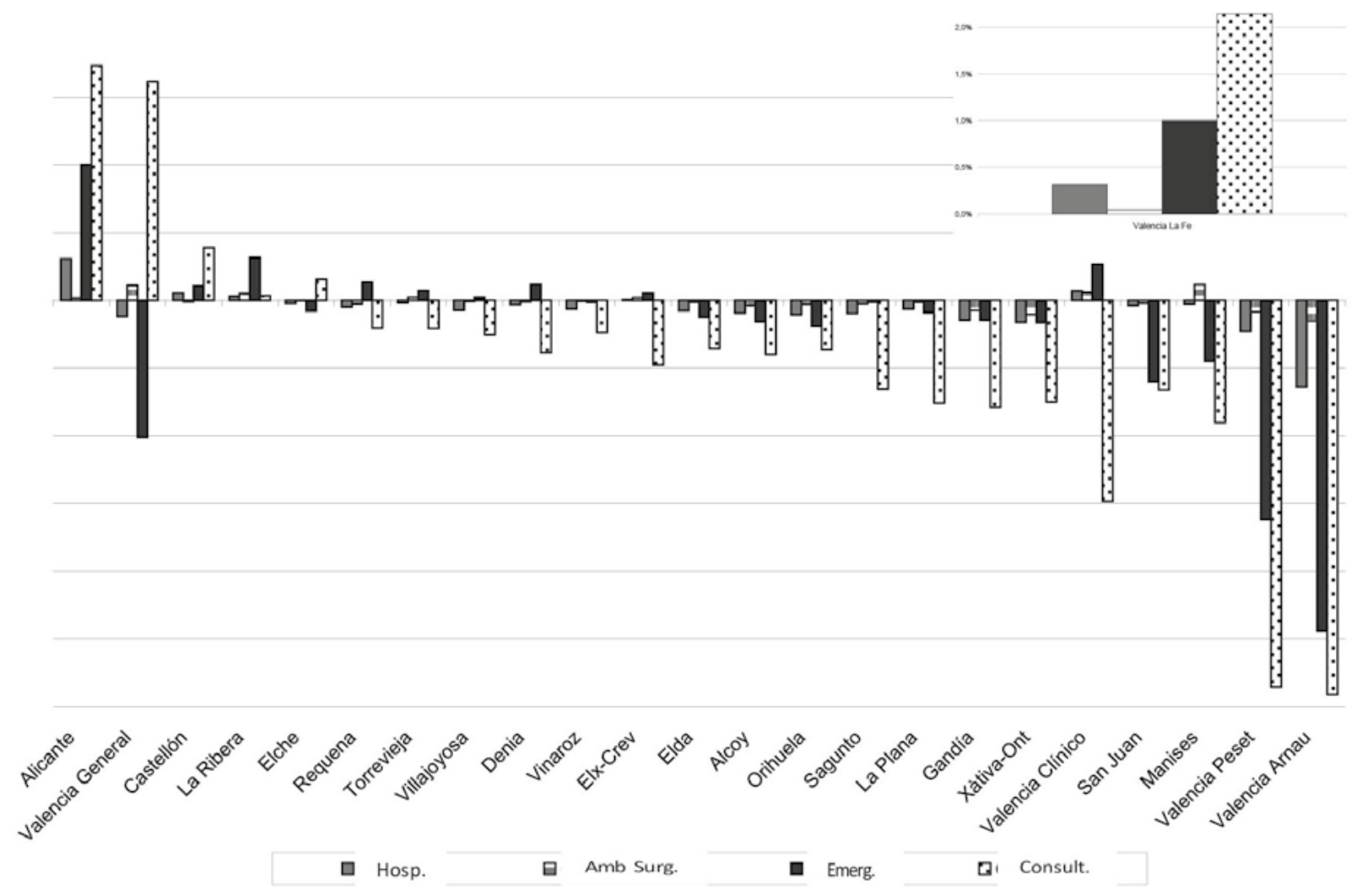

Figure 3. Market share increase by healthcare type 


\section{Discussion}

The present study has set as object to observe the patient loyalty behavior by the healthcare assistance type within a setting in which the public sector management coexists with a formula of public-private partnership, the Alzira Model, that has a history and has consolidated in the Valencian Community (Spain). From the results obtained in the calculation of the chosen parameters as loyalty strategic variables, following conclusions can be drawn:

- All analyzed parameters show that the higher patient flows take place in two healthcare types - emergencies and outpatient consultancy—, where the patients' loyalty behavior is lower than in the hospitalization and ambulatory surgery types.

- There is an irregular growth in the net patients' base, where three departments increase their base in all healthcare departments, whereas 11 departments showing a reduced net patients' base in all healthcare types, thus causing direct repercussions in terms of management, since the number of attended patients decreases, especially if the department revenues directly depend on the patient attendance, as it is the case of the capitation and the interinstitutional turnover financing models, which is the existing scenario in the Valencian Community.

- The departments with an public-private partnership (Alzira Model) management show an extremely low patient dropout. In other words, it seems that this specific healthcare management model favors maintaining the relation with the patient, except for Manises.

- Manises presents an augmented number of patient turnover, both in acquisition and in dropout, with a substantial impact on its natural growth rate. In this regard, a factor of direct impact was found: the proximity of this healthcare department to the Valencian capital city, attracting therefore patients to other larger medical centers.

- The results of the concessions contrasted with ambulatory surgery stand out, in which a greater degree of specialization is observed for this healthcare type.

- The behavior expressed by the patients of the public-private concessions is not homogeneous, where the best results are presented by La Ribera, with net growth of its patients' base, thus increasing its market share in the studied four healthcare types. In this way, considering the two analyzed healthcare service management types (public sector management and public-private partnership or concession), it can be concluded that the management type does not determine the patient's loyalty behavior, but, on the other hand, the shown disparity leads to state that it is the management performed in each department, as well as the external factors (distance to the capital city, years of experience of the hospital, etc.), what generates the patients' preferences when it comes to receiving healthcare assistance. 
These conclusions, firstly, validate works like the ones of Moliner and colleagues and Civera, which identify differences in the patient's behavior towards public, private and in partnership hospitals $(42,43)$. Even though, going one step forward, there are differences within each management model, being the performed management more decisive than the model per se. In this way, the relevance of the management becomes evident when it comes to achieve the patient's loyalty, so that the key to retaining patients is to provide added value, a personalized service, and a satisfaction that exceed the expectations, with a clear strategic patient-focused orientation $(44,45)$. Likewise, the foregoing provides a wider understanding of the patient's behavior in relation to different healthcare management models, and in line with works like Carreño and Nel's (46). In this way, this and other related analyses become particularly relevant in the current scenario in which the public-private partnership (Alzira Model) is increasingly being socially and politically questioned and when the healthcare management needs to look for economically and socially more sustainable formulas with the purpose of achieving the best satisfaction of the patient.

In the second place, this study contributes to the acquisition of knowledge for managers and researchers of the healthcare service for the purpose of designing the service portfolio, promoting specialization in certain healthcare assistance types. Even going one step further, knowing the patient's loyalty behavior, differentiating by healthcare type could be the basis for designing and establishing classic marketing strategies such as segmentation, differentiation and positioning. As is generally known, segmentation helps setting priorities by bringing to light the provided healthcare and the healthcare that should be provided to each segment, thus allowing the making of strategic and managerial decisions and contributing to the customers' loyalty by allowing meeting their needs $(16,47-51)$. On its part, differentiation is a significant basis for distinguishing the services of one healthcare service provider from another, whereby different authors advocate for a strategy based on differentiation, due to the consequences on the consumer's attitudes and loyalty behavior (15, 38, 52-54). Ultimately, positioning allows establishing and maintaining a distinctive position in the mind of the service enduser, since the adopted approach reflects the way in which the consumer perceives the organization, its service and features $(51,55,56)$. In short, a circular sequence is drawn, in which knowing to which healthcare type the patient shows a higher loyalty contributes to designing the service portfolio with a strategic perspective, even using marketing instruments that can potentiate this higher loyalty. All of this is of greater relevance even more in competitive environments, with public-private partnership, for its direct impact on the service financing. 


\section{References}

1. Suárez N. Mercadotecnia y gestión sanitaria. Rev Cub Salud Pública. 2002;28(2):201-23.

2. Copeland M. Relation of consumer's buying habits to marketing methods. Harv Bus Rev. 1923;1:282-89.

3. Brown G. Brand loyalty - Fact or fiction? Advert Age. 1952;23:53-5.

4. Cunningham SM. Brand loyalty - What, where, how much? Harv Bus Rev. 1966;34:116-28.

5. Kuehn A. Consumer brand choice - A learning process? In: Frank R, Kuehn A, Massy, W. editors. Quantitative techniques in marketing analysis. Irwin: Homewood; 1962.

6. Hirschman AO. Exit, voice and loyalty. Cambridge: Harvard University Press; 1970.

7. Sheth JN, Park CW. A theory of multidimensional brand loyalty. Illinois: Faculty Working Papers. College of Commerce and Business Administration, University of Illinois at Urban-Champaign; 1974.

8. Kotler P, Clarke RN. Marketing for health care organizations. New Jersey: Prentice-Hall; 1987.

9. Gilligan C, Lowe R. Marketing and health care organizations. New York: Radcliffe Medical Press; 1995.

10. Gallarza MG. Fidelidad versus lealtad: ¿clientes “perros” o “amigos”? Harvard Deusto Business Review. 2002;107:56-61.

11. Quintano M. La dinámica de la lealtad del cliente: un acercamiento teórico. In: Alfaro, M. (coordinators), Temas clave en marketing relacional. Madrid: McGraw-Hill; 2004 p. 27-48.

12. Robinson S, Etherington L. Customer loyalty: a guide for time travellers. New York: Palgrave Macmillan; 2004.

13. Alcaide JC. Fidelización de clientes. Madrid: esic Editorial; 2010.

14. Jacoby J, Chestnut RW. Brand loyalty: measurement and management. New York: John Wiley \& Sons; 1978.

15. Dick AS, Basu K. Customer loyalty: toward an integrated conceptual framework. J Acad Mark Sci. 1994;22:99-113.

16. Cobra M. Marketing de servicios. Madrid: McGraw-Hill; 2000.

17. Jacoby J, Kyner DB. Brand loyalty vs. repeat purchasing behavior. Journal of Marketing Research. 1973;10(1):1-9. Dor: 10.2307/3149402

18. Bloemer J, Ruyter K. Customer loyalty in high and low involvement service settings: The moderating impact of positive emotions. Journal of Marketing Management. 1999;15(4):315-30. DoI: 10.1362/026725799784870388

19. Lu IY, Yang CY, Chiu SC, Tseng CJ. The study of repurchase intention in sense of experiential marketing. Paper presented at the $6^{\text {th }}$ Asian Network for Quality Congress, Thailand; 2008.

20. Rundle-Thiele S, Russell-Bennett R. Patient influences on satisfaction and loyalty for GP services. Health Mark Q. 2010;27(2):195-214. Dor: 10.1080/07359681003745162 
21. Gremler DD, Brown SW. Service loyalty: Its nature, importance, and implications. In: Edvardsson B, Brown SW, Johnston R, Scherring E. editor, QUIS V: Advancing service quality: A global perspective New York: International Service Quality Association; 1996 p. 171-181.

22. Spake DF, Bishop JS. The impact of perceived closeness on the differing roles of satisfaction, trust, commitment, and comfort on intention to remain with a physician. Health Mark Q. 2009; 26(1):1-15. Dor: 10.1080/07359680802473281

23. Torres E, Vásquez-Parraga AZ, Barra C. The path of patient loyalty and the role of doctor reputation. Health Mark Q 2009;26(3):183-197. Dor: 10.1080/07359680903263565

24. Roberge D, Beaulieu MD, Haddad S, Lebeau R, Pineault R. Loyalty to the regular care provider: Patients' and physicians’ views. Fam Pract. 2001;18:53-9. Dor: 10.1093/fampra/18.1.53

25. Freeman G, Hjortdahl P. What future for continuity of care in general practice? BMJ. 1997;314(7098):1870-3. Dor: 10.1136/bmj.314.7098.1870

26. Naidu GM, Parvatiyar A, Sheth JN, Westgate L. Does relationship marketing pay? An empirical investigation of relationship marketing practices in hospitals. J Bus Res. 1999;46:207-18. DoI: 10.1016/S0148-2963(98)00044-7

27. Zeithaml V, Berry LL, Parasuraman A. The behavioral consequences of service quality. J Mark. 1996;60:31-46. DOI: 10.2307/1251929

28. Pritchard MP, Havitz ME, Howard DR. Analyzing the commitment-loyalty link in service contexts. J Acad Mark Sci. 1999;27(3):333-48.

29. Cronin JJ, Brady MK, Hult GTM. Assessing the effects of quality, value, and customer satisfaction on consumer behavioral intentions in service environments. Journal of Retailing. 2000;76(2):193-218. Dor: 10.1016/S0022-4359(00)00028-2

30. Brady MK, Robertson CJ. Searching for a consensus on the antecedent role of service quality and satisfaction: an exploratory cross-national study. J Bus Res. 2001;51:53-60. DOI: 10.1016/S0148-2963(99)00041-7

31. Cenzig E, Kirkbir F. Customer perceived value: the development of a multiple item scale in hospitals. Problems and Perspectives in Management. 2007;5(3):252-68.

32. Han X, Kwortnik RJ, Wang C. Service loyalty: an integrative model and examination across service contexts. J Serv Res. 2008;11(1):22-42.

33. MacStravic RS. Creating consumer loyalty in healthcare. Chicago: Health Administration Press; 1999.

34. Reichheld FF. The loyalty effect. Boston: Harvard Business School Press; 1996.

35. Consell de la Generalitat Valenciana. Decreto 25/2005, (2005 feb 04).

36. Filip A, Voinea L. Understanding the processes of customer acquisition, customer retention and customer relationship development. International Journal of Economic Practices and Theories. 2012;2(2):62-7.

37. Mellens M, Dekimpe MG, Steenkamp JBEM. A review of brand-loyalty measures in marketing. Tijdschrift voor economie en management. 1996;XLI (4):507-33.

38. Kotler P, Keller KL. Dirección de marketing. Madrid: Pearson Educación; 2006. 
39. Gummerson E. Total relationship marketing. Oxford: Butterworth-Heinemann; 2008.

40. Calero R, Gallarza MG. Identificación de diagnósticos y especialidades con mayor lealtad del paciente como fuente de ventaja competitiva. Horizonte sanitario. 2016;15(3):105-21.

41. Base de datos compas.

42. Moliner MA, Callarisa LJ, Rodríguez RM. La explicación del comportamiento de lealtad desde la teoría de la actitud: una aplicación a usuarios de hospitales. In: Asociación Española de Dirección y Economía de la Empresa (AEDEM) (editors) Decisiones basadas en el conocimiento y en el papel social de la empresa. Palma de Mallorca: Aedem; 2007, p. 13.

43. Civera M. Análisis de la relación entre calidad y satisfacción en el ámbito hospitalario en función del modelo de gestión establecido [tesis doctoral], [Castellón de la Plana]: Universitat Jaume I; 2008.

44. Durán SG. La calidad en el servicio como principal fidelizador en el sector salud. [tesis doctoral]. [Bogotá]: Universidad de La Sabana; 2013.

45. Riveros J, Berné C. Análisis de la opinión de usuarios sobre calidad percibida y satisfacción con hospitales públicos: estudio de caso desde la perspectiva de la aplicación del marketing. Rev Med Chil. 2007;135(7):862-70. Dor: 10.4067/S0034-98872007000700006

46. Carreño R, Nel J. Bioética y universidad: el hospital universitario, ¿público o privado? Rev Cienc Salud. 2007;5(3):91-101.

47. Esteban IG. Marketing de los servicios. Madrid: ESIC Editorial; 2000.

48. Rivera J, Arellano R, Molero VM. Conducta del consumidor, estrategias y políticas aplicadas al marketing. Madrid: esic Editorial; 2009.

49. Allenby G, Fennell A, Bemmaor A, Bhargava V, Christen F, Dawley J, et al. Market segmentation research: beyond within and across group differences. Mark Lett. 2002;13(3):233-43.

50. Dalrymple DJ, Parsons LS. Marketing management: text and cases. California: Wiley Ed; 1976.

51. Lovelock CH. Services marketing. New Jersey: Prentice Hall International Editions; 1996.

52. Chamberlin EH. Product heterogeneity and public policy. Am Econ Rev. 1950;40(2):85-92.

53. Lambin JJ. Marketing estratégico. Madrid: esic Editorial; 2003.

54. Oliver RL. Whence consumer loyalty? J Mark. 1999; 63:33-44.

55. Ortigueira Bouzada M, Ortigueira Sánchez M. El sistema sanitario público, sus servicios y sus responsables: creación y pilotaje de su imagen. Cuadernos de Gestión. 2001;1(1):67-103.

56. Berkowitz EN. Essentials of health care marketing. 3rd ed. Burlington: Jones \& Bartlett Learning; 2010. 